\title{
Mega debris flow deposits on the western Wilkes Land margin, East Antarctica
}

\author{
F. Donda, ${ }^{1}$ P. E. O’Brien, ${ }^{2}$ L. De Santis, ${ }^{1}$ M. Rebesco,,${ }^{1}$ and G. Brancolini ${ }^{1}$ \\ ${ }^{1}$ Istituto Nazionale di Oceanografia e di Geofisica Sperimentale (OGS), Borgo Grotta Gigante, 42/c, 34010 Sgonico (Trieste), Italy (fdonda@inogs.it; \\ 1desantis@inogs.it; mrebesco@inogs.it; gbrancolini@inogs.it) \\ ${ }^{2}$ Petroleum and Marine Division, Geoscience Australia, GPO Box 378 Canberra, ACT 2601, Australia (Phil.OBrien@ga.gov.au)
}

\begin{abstract}
Multichannel seismic data collected off Western Wilkes Land (East Antarctica) reveal the occurrence of mega debris flow deposits on the lower slope and rise that were formed throughout the Miocene. Commonly, debris flow units are separated by thin deposits of well-stratified facies, interpreted as predominantly glaciomarine mixed contouritic and distal turbidite deposits. These units could act as weak layers and could have played a major role in the slope instability. High sedimentation rates, due to large amounts of sediment delivered from a temperate, wet-based ice sheet, constituted a key factor in the sediment failures. The main trigger mechanism would probably have been earthquakes enhanced by isostatic rebound following major ice sheet retreats.

Citation: Donda, F., O’Brien, P.E., De Santis, L., Rebesco, M., and Brancolini, G. (2007), Mega debris flow deposits on the Western Wilkes Land margin, East Antarctica, in Antarctica: A Keystone in a Changing World - Online Proceedings of the $10^{\text {th }}$ ISAES, edited by A. K. Cooper and C. R. Raymond et al., USGS Open File Report 2007-1047, Short Research Paper 040, 4 p.; doi:10.3133/of2007-1047.srp040
\end{abstract}

\section{Introduction}

Mass wasting is a common mechanism, both in lowlatitudes and along high-latitude glaciated margins, that redistributes shelf-edge and upper-slope sediment downslope by various gravity-driven processes. Glaciated margins are known for the importance of mass-movement deposition. Glaciers can be highly effective agents of erosion and can deliver large amounts of sediments to the continental slope, making gravitational instability of the resulting deposits more likely (e.g. Dowdeswell et al., 1998, Bryn et al., 2005a and b; Rise et al., 2005 and 2006). In comparison to the Northern Hemisphere, there are fewer descriptions of mass flow deposits from the Antarctic margin (Bart et al., 1999; Imbo et al., 2003; Diviacco et al., 2003).

Here we present a synthesis of the main results of seismostratigraphic analyses performed on multichannel seismic data collected since the 1980's in Western Wilkes Land (i.e. between $110^{\circ}$ and $130^{\circ}$ E, Fig. 1), by Japan National Oil Corporation, available through the Seismic Data Library System (SDLS), and by Geoscience Australia. These data image widespread mass-movement deposits on the continental slope and rise, including huge debris flow deposits (DFDs).

The main aim of this paper is to investigate a possible relationship between the sedimentary processes, which led to the formation of widespread mass-movements, and the fluctuation of the extent of the ice sheet in this part of the East Antarctic margin.

\section{Cenozoic depositional environment of the western Wilkes Land margin}

Several seismic-stratigraphic analyses have been performed since the 1980's over a large portion of the Wilkes Land margin (i.e. between $135^{\circ}$ and $150^{\circ} \mathrm{E}$; Sato et al., 1984; Eittreim and Smith, 1987; Hampton et al., 1987; Tanahashi et al., 1987 and 1994; Eittreim et al., 1995; Ishihara et al., 1996; Escutia et al., 1997 and 2000; De Santis et al., 2003; Donda et al., 2003). More recently, Donda et al. (2007) suggest that the nine seismic sequences identified by De Santis et al. (2003) can be grouped into four distinct packages or chronostratigraphic

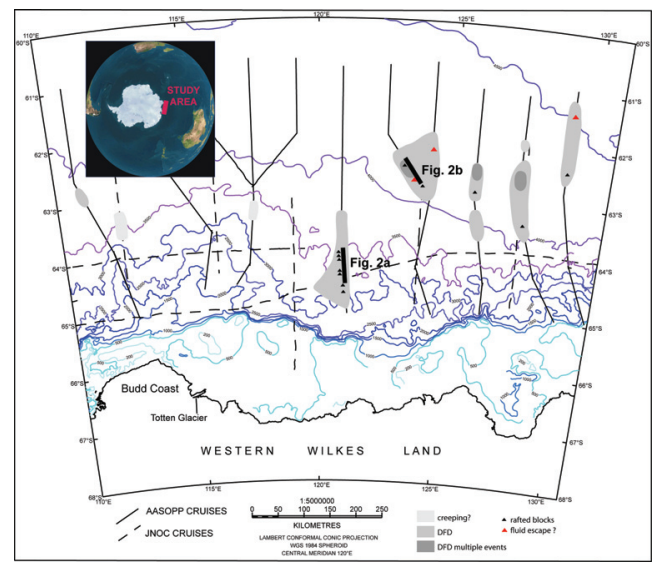

Figure 1. Satellite bathymetric map (GEBCO) and location of multichannel seismic lines collected off Western Wilkes Land. The distribution of the mass wasting-related deposits is also indicated (from Donda et al., in press; modified)

"units", named Unit 1 to Unit 4 from the oldest to the youngest, representing different phases in the MesozoicCenozoic evolution of the Wilkes Land margin (Phase 1 to Phase 4). During Phase 1 (?Late Cretaceous-?Early Oligocene) this margin was probably ice-free, although some limited mountain glaciers may have been present (Strand et al., 2003). Phase 2 (?Early Oligocene-?Early Miocene) records a progressive increase in sediment input from the continent, due to a highly dynamic ice sheet producing abundant meltwater and eroding the continent rapidly (see also Cooper and O'Brien, 2004). During the ?Early-?Late Miocene (Phase 3), major submarine channels developed on the continental slope and rise, and gravity-driven processes were dominant. During Phase 4 (?Pliocene-Recent), thick, prograding shelf-edge wedges deposited on the continental shelf and slope, and sediment transport to the outer shelf was strongly reduced. This 
would reflect that the ice sheet was progressively less dynamic than during Phase 3, and that a transition to colder, more polar regimes occurred (Donda et al., 2007).

\section{Main characteristics of the mega debris flow deposits of western Wilkes Land margin}

The eastern and central sector of the study area, i.e. between $120^{\circ}$ and $130^{\circ} \mathrm{E}$, are characterized by the presence of tabular to lenticular, internally chaotic to semi-transparent sediment bodies (Fig. 2), which we interpret as debris flow deposits (DFDs). They are underlain by a high-amplitude reflector, which in places corresponds to a heavily eroded surface. The upper bounding surface of the DFDs is commonly characterized by an irregular to hummocky relief.

These DFDs extend up to $200 \mathrm{~km}$ in seaward direction and their thickness locally reaches $400 \mathrm{~m}$. As such, they can be classified as "mega debris flow deposits", according to Diviacco et al. (2003). In particular in the eastern sector of the study area (i.e. between $125^{\circ}$ and $130^{\circ} \mathrm{E}$ ), the DFDs are characterized by a length of 150 $210 \mathrm{~km}$ and a thickness of $175-350 \mathrm{~m}$.
In the central sector of the study area (i.e between $120^{\circ}$ and $125^{\circ} \mathrm{E}$ ), debris flows show seaward extents of 100 to $180 \mathrm{~km}$ (Fig. 2). Thicknesses range from 90 to 250 $\mathrm{m}$, with maximum values of $400 \mathrm{~m}$ in areas more proximal to the margin. This is the thickest debris flow in the whole area, buried below a 450-m-thick, wellstratified facies, interpreted as representing contour current-related deposits (O’Brien et al., 2006).

DFDs occur as multiple events within Unit 3 and are separated by thin deposits of well-stratified facies (Fig. $2 b$ ), interpreted to consist of glaciomarine mixed contouritic and distal turbidite deposits, possiby with some hemipelagic component (see also Donda et al., 2007). DFDs are also generally overlain by well-stratified facies, attributed to Unit 4 deposits (Fig. 2). Locally, mound-shaped or pyramid-shaped, interally chaotic features, bounded by medium amplitude reflectors, protruding into overlying facies have been identified within the DFDs (Fig. 2a). It is suggested that they could represent rafted blocks, ranging from 1 to more than $3 \mathrm{~km}$ in width.

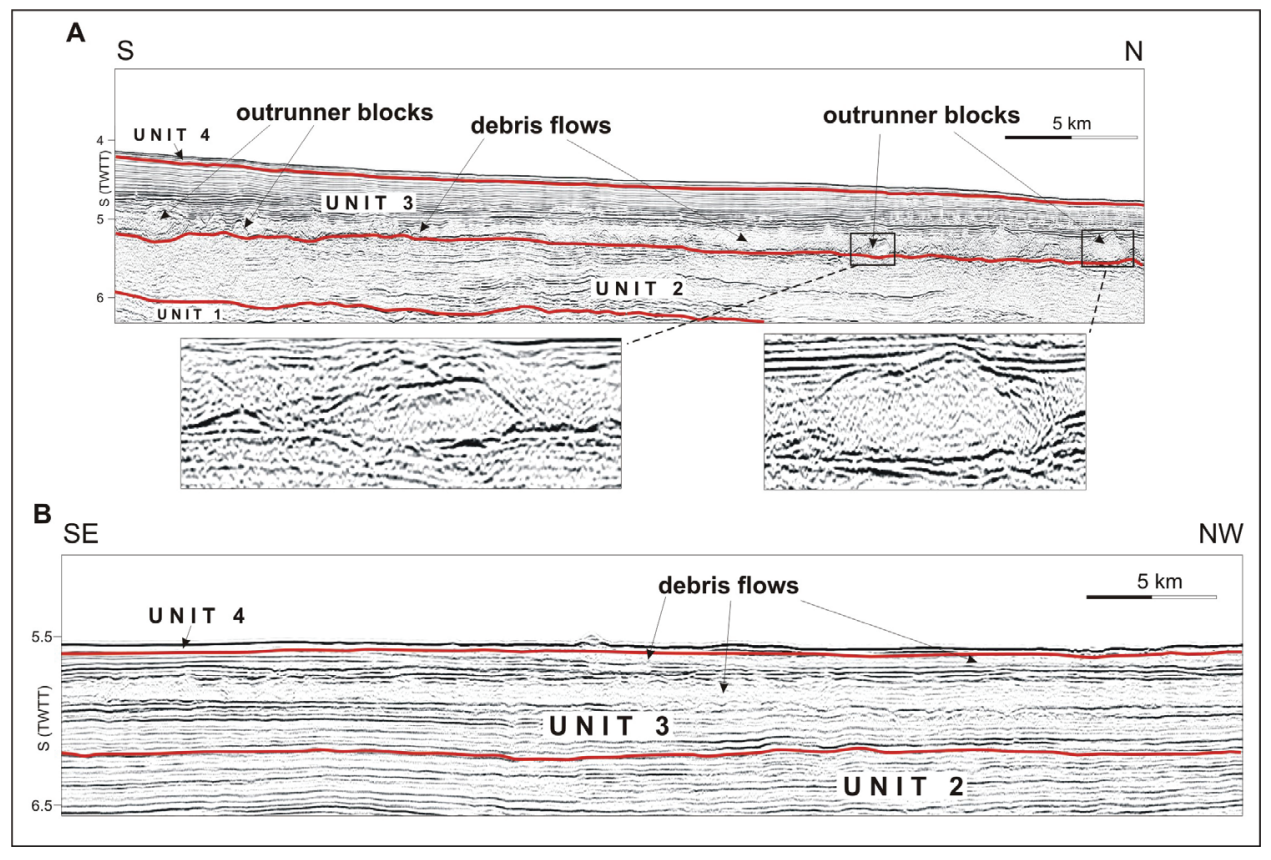

Figure 2. a) Part of multichannel seismic line GA228/21, showing debris flows containing numerous outrunner blocks; b) Part of the multichannel seismic lines GA228/08, imaging DFDs deposited as multiple events (from Donda et al., in press; modified).

\section{Age control}

In Western Wilkes Land margin, sediments involved in the mass-movements post-date the regional unconformity known as WL2 (Tanahashi et al., 1994; Eittreim et al., 1995, Escutia et al., 1997 and 2000), WLU3 (De Santis et al., 2003; Donda et al., 2003; Donda et al., 2007), or eoc (Close et al, 2007), likely Eocene in age.
In order to provide a better estimation of the age of the DFDs, lines that intersect DSDP Site 268 (Hayes, Frakes et al., 1975), approximatively $300 \mathrm{~km}$ east of our study area, have been examined. This site is tied by seismic lines GA228/16, TH83-10 and TH94-19, that show the same seismic stratigraphic styles described by Donda et al. (2007). The stratigraphy in Site 268 would suggest that 
Phase 4 was of Pliocene to Pleistocene age and that Phase 3 represents sedimentation during the Miocene. The position of the mass-movement deposits therefore suggests they formed at various times during the Miocene.

\section{Discussion}

The exceptional sizes of the DFDs likely resulted from an amalgamation of several, smaller debris flows, which were part of a multiphase failure event, as also suggested by Diviacco et al. (2003) for the Alexander Channel debris flow in the Antarctic Peninsula. The capacity of the DFDs to incorporate and transport bedload material is demonstrated by the occurrence of numerous rafted blocks. The DFDs reveal also an extraordinary mobility, as demonstrated by their very long run-out distances, comparable with the Storegga and Traenadjupet slides (Laberg and Vorren, 2000; Laberg et al., 2002; Bryn et al., 2005 a, b; De Blasio, 2005; Kvalstad et al., 2005). De Blasio et al. (2005) suggested that long run-outs are due to progressive loss of strenght during the downslope movement of the debris flows, possibly related to water entrainment underneath the flowing sediments. Such process is known as "hydroplanning" (Harbitz et al., 2000). It is then suggested that the long run-out distances of the Western Wilkes Land margin DFDs could be related to hydroplanning processes, as a consequence of a progressive loss of yield strength (Canals et al., 2004).

In the Western Wilkes Land margin, approximatively off the Totten Glacier terminus, the maximum sediment thickness (about $850 \mathrm{~m}$ ) of deposits attributed to Unit 3 has been recorded (O'Brien et al., 2006; Donda et al., in press). High sedimentation rates could be possibly related to the progressive growth and evolution of the East Antarctic Ice Sheet. During the Miocene, high sedimentation rates are expected to occur in the Wilkes Land as a consequence of high discharge of meltwater at the base of a highly dynamic, wet-based temperate ice sheet. Under such conditions, excess porewater pressure was possibly created. Overpressure would have been generated within the intercalated sediments made of predominant contouritic deposits, possibly deposited during glacial retreats. These intercalated sediments would have behaved as weak layers and glide planes.

The main influence of countourites on slope instability relates to their high water and clay content and plasticity (Kvalstad et al., 2005; Bryn et al., 2005b). It is then suggested that contouritic deposits in the Western Wilkes Land can also have played a role in the slope instability, representing weak layers above which sediments were prone to slide. The occurrence of multiple DFDs on different stratigraphic levels would indicate that this part of the continental margin has been unstable for a long time, i.e. at least during the deposition of Unit 3, Miocene in age.

The lack of DFDs in the western sector of the study area could be related to the amount of meltwater discharge. In general, large meltwater discharges favour rapid, proximal initiation of turbidity currents and relative sediment starvation on the upper slope (O'Cofaigh et al., 2003). In the Wilkes Land margin, Donda et al. (2007) suggested that large amounts of glacial meltwater eroded and delivered sediments from the continental shelf to the slope and rise area during Phase 3. However, meltwater discharge possibly did not occur in a similar way all along the margin, with some areas delivering larger amounts of water. Large debris flows in the eastern and central sector of the study area would suggest a less important role for melwater in transporting sediment to the rise than further west.

\section{Trigger mechanisms}

As it has been suggested for several Northern Hemisphere slide events, excess pore pressure could be invoked as main trigger mechanism for the Wilkes Land mass-wastings, deposited during high sedimentation rates as a consequence of high discharge of meltwater.

As a final trigger mechanism, earthquake activity associated with post-glacial isostatic rebound could be invoked. During the Miocene, and especially during the Middle-Late Miocene, variations in eustatic sea level and in oxygen isotope records would be related to major ice sheet fluctuations (see Fig. 11 of Donda et al., 2007). Moreover, the previous notion that Antarctica is essentially aseismic has been recently disproved, and loading and partial unloading of ice cover has been proposed as one of the main factors controlling seismic activity (Reading, in press). In Wilkes Land, earthquakes presently occur in the continental shelf and rise area, with some events reaching magnitudes of 5.0 (Reading, 2002; Reading, in press). It is then reasonable to suggest that strong earthquakes occurred in the study area also throughout the Miocene, when isostatic rebounds were caused by multiple advances and retreats of a highly dynamic ice sheet.

\section{Conclusions}

Seismostratigraphic analyses performed on multichannel seismic data collected off Western Wilkes Land (East Antarctica) reveal the occurrence of widespread mass flow events throughout the Miocene.

Mega debris flows deposited as multiple events on the continental slope and rise, locally containing large rafted blocks. The uppermost part of the Western Wilkes Land margin stratigraphic sequence, Pliocene to Recent in age, is not affected by major slope failure. In some areas, debris flow units are separated by thin deposits of wellstratified facies, interpreted as predominantly glaciomarine mixed contourites and distal turbidites. It is suggested that these units, due to a dominant contouritic component, may represent weak layers and could play a major role in the slope instability. High sedimentation rates, due to large amounts of sediment delivered from a temperate, wet-based ice sheet, and consequent excess pore pressures are suggested to have played a major role in Western Wilkes Land margin sediment failures. The 
final trigger mechanism would be related to the high dynamism of the ice sheet, characterized by large fluctuations during the Miocene. Isostatic rebound following major ice sheet retreats could be possible at the origin of large earthquakes, leading to the failure of sediments already prone to slide.

Acknowledgments. The first author is grateful to the Petroleum and Marine Division of Geoscience Australia for the hospitality and technical support. Howard Stagg is in particular acknowledged for valuable discussions and suggestions. Special thanks to German Leitchenkov and Marc De Batist for their comments on the manuscript, and to the co-editor Phil Bart. This study is funded by the Italian Programma Nazionale di Ricerche in Antartide (PNRA) and by the Consiglio Nazionale delle Ricerche (CNR) in the frame of the international "Short-Term Mobility" project.

\section{References}

Bart, P. J., M. De Batist, and W. Jokat (1999), Interglacial collapse of Crary trough-mouth fan, Weddel Sea, Antarctica: implications for Antarctic glacial history, J. Sediment. Res., 69, 1276-1289.

Bryn, P., K. Berg, C. F. Forsberg, A. Solheim, and T. J. Kvalstad (2005a), Explaining the Storegga Slide, Mar. Petr. Geol., 22, 11-19.

Bryn, P., K. Berg, M. S. Stoker, H. Haflidason, and A. Solheim (2005b), Contourites and their relevance for mass wasting along the Mid-Norwegian Margin, Mar. Petr. Geol., 22, 85-96.

Canals, M., G. Lastras, R. Urgeles, J. L. Casamor, J. Mienert, A. Cattaneo, M. De Batist, H. Haflidason, Y. Imbo, J. S. Laberg, J. Locat, D. Long, O. Longva, D. G. Masson, N. Sultan, F. Trincardi, and P. Bryn (2004), Slope failure dynamics and impacts from seafloor and shallow sub-seafloor geophysical data: case studies from the COSTA project, Mar. Geol., 213, 9-72.

Close, D. I., H. M. J. Stagg, P. E. O’Brien, 2007, Seismic stratigraphy and sediment distribution of the Wilkes Land and Terre Adelie margins, East Antarctica, Mar Geol., 239, 33-57.

Cooper, A. K. and P. E. O'Brien (2004), Leg 188 Synthesis: Transitions in the glacial hystory of the Prydz Bay region, East Antarctica, from ODP drilling, in Proc. ODP, Sci. Results 188, edited by A. K. Cooper, P. E. O'Brien and C. Richter, pp. 1-42, College Station, Texas.

De Blasio, F. V., A. Elverhoi, D. Issler, C. B. Harbitz, P. Bryn, and R. Lien (2005), On the dynamics of subacqueous clay rich gravity mass flows-the giant Storegga Slide, Norway, Mar. Petrol. Geol., 22, 179-186.

De Santis, L., G. Brancolini and F. Donda (2003), Seismo-stratigraphic analysis of the Wilkes Land continental margin (East Antarctica): influence of glacially-driven processes on the Cenozoic deposition, Deep-Sea Res., 50, 1563-1594.

Diviacco, P., M. Rebesco, A. Camerlenghi (2003), Late Pliocene mega debris flow deposits and related fluid escapes identified on the Antarctic Peninsula continental margin by seismic reflection data analysis. Mar. Geophys. Res., 27, 2, 109-128.

Donda, F., G. Brancolini, L. De Santis, and F. Trincardi (2003), Seismic facies and sedimentary processes on the continental rise off Wilkes Land (East Antarctica): evidence of bottom current activity, Deep-Sea Res., 50, 1509-1527.

Donda F., G. Brancolini, P. E. O'Brien, L. De Santis, and C. Escutia (2007), Sedimentary processes in the Wilkes Land margin: a record of the Cenozoic East Antarctic Ice Sheet evolution, J. Geol. Soc. London, 164, 243-256

Donda F., P. E. O'Brien, L. De Santis, G. Brancolini, and M. Rebesco, Mass wasting processes in the Western Wilkes Land margin: possible implications for the East Antarctic glacial history, Palaeogeogr., Palaeoclimatol., Palaeoecol., in press.

Dowdeswell, J. A., A. Elverhoi, and R. Spielhagen (1998), Glacimarine sedimentary processes and facies on the polar North Atlantic Margins, Quat. Sc. Rev., 17, 243-272.

Eittreim, S. L., and G. L. Smith (1987), Seismic sequences and their distribution on the Wilkes Land Margin, in The Antarctic Continental Margin: Geology and Geophysics of Offshore Wilkes Land, edited by S. L Eittreim, and M. A. Hampton, pp. 15-43, Circum-Pacific Council for Energy and Mineral Resources, Houston, Texas.

Eittreim, S. L., A. K. Cooper, and J. Wannesson (1995), Seismic stratigraphy evidence of ice-sheet advances on the Wilkes Land margin, Sediment. Geol., 96, 131-156.
Escutia, C., S. L. Eittreim, and A. K. Cooper (1997), Cenozoic glaciomarine sequences on the Wilkes Land continental rise, Antarctica, in Proceedings Volume, VIIth International Symposium on Antarctic Earth Sciences, edited by C. A.Ricci, pp. 791-795, Siena, Italy.

Escutia, C., S. L. Eittreim, A. K. Cooper, and C. H. Nelson (2000), Morphology and acoustic character of the Antarctic Wilkes Land turbidite system: ice-sheet-sourced versus river-sourced fans, J. Sediment. Res., 70, $1,84-93$.

Hampton, M. A., S. L. Eittreim, and B. M. Richmond (1987), Post-breakup sedimentation on the Wilkes Land margin, in The Antarctic Continental Margin: Geology and Geophysics of Offshore Wilkes Land, edited by S. L. Eittreim, and M. A. Hampton, pp. 75-88, Circum-Pacific Council for Energy and Mineral Resources, Houston, Texas.

Harbitz, C., A. Elverhoi, D. Mohrig, G. Parker and P. Dimakis (2000), Hydroplaning of muddy debris flows: theoretical descriptions and applications on high-latitude glacigenic deep sea fans, NGI Report 5220912, rev. 1, Norges Geotekniske Institutt, Oslo, Norway.

Hayes, D. E., L. A. Frakes, and the Shipboard Scientific Party (1975), Initial Reports of the Deep Sea Drilling Project, 28, US Government Printing Office, Washington, DC.

Imbo, Y., M. De Batist, M. Canals, M. J. Prieto, and J. Baraza (2003), The Gebra Slide: a submarine slide on the Trinity Peninsula Margin, Antarctica, Mar. Geol., 193, 235-252.

Ishihara, T., M. Tanahashi, M. Sato, and Y. Okuda (1996), Preliminary report of geophysical and geological surveys of the Western Wilkes Land margin, Proc. NIPR Symp. Ant. Sc. 9, 91-108.

Kvalstad, T. J., L. Andresen, C. F. Forsberg, K. Berg, P. Bryn, and M. Wangen (2005), The Storegga slide: evaluation of triggering sources and slide mechanics, Mar. Petr. Geol., 22, 245-256.

Laberg, J.S. and Vorren, T.O. (2000), The Traenadjupet Slide, offshore Norway: morphology, evacuation and triggering mechanisms. Mar. Geol., $171,95-114$.

Laberg, J.S., Vorren, T.O., Mienert, J., Bryn, P. and Lien, R. (2002), The Traenadjupet Slide: a large slope failure affecting the continental margin of Norway 4000 years ago. Geo-Mar. Lett. 22 (1), 19-24.

O'Brien, P. E., S. Stanley, and R. Parums (2006), Post-rift continental slope and rise sediments from $38^{\circ} \mathrm{E}$ to $164^{\circ} \mathrm{E}$, East Antarctica, in Antarctica: contributions to global earth sciences, edited by D. K. Fuetterer, D. Damaske, G. Kleinschmidt, H. Miller, and F. Tessensohn, pp. 341-348, Springer-Verlag, Berlin Heidelberg New York.

O'Cofaigh, C., J. Taylor, J. A. Dowdeswell and C. J. Pudsey (2003), Palaeoice streams, trough mouth fans and high-latitude continental slope sedimentation, Boreas, 32, 37-55.

Reading, A. M. (2002), Antarctic seismicity and neotectonics, in Antarctica at the close of a millenium, edited by J. A. Gamble, D. N. B. Skinner, S. Henrys, pp. 479-484, Royal Soc. New Zeal. Bull., 35.

Reading, A. M., The seismicity of the Antarctic Plate, in Continental intraplate earthquakes: science, hazard, and policy issues, edited by $\mathrm{S}$. Stein, and S. Mazzotti, Geol. Soc. Am. Mon., in press.

Rise, L., D. Ottesen, O. Longva, A. Solheim, E. S. Andersen and S. Ayers (2006), The Sklinnadjupet slide and its relation to the Elsterian glaciation on the mid-Norvegian margin, Mar. Petr. Geol., 23, 569-583.

Rise, L., D. Ottesen, K. Berg, and E. Lundin (2005), Large-scale development of the mid-Norwegian margin during the last 3 million years, Mar. Petr. Geol., 22, 33-44.

Sato, S., N. Asakura, T. Saky, N. Oikawa, and Y. Kaneda (1984), Preliminary results of geological and geophysical surveys in the Ross Sea and in the Dumond d'Urville Sea, off Antarctica, Mem. Natl. Inst. Pol. Res., 33, 6692.

Strand, K., Passchier, S. and Näsi, J. (2003), Implications of quartz grain microtextures for onset of Eocene/Oligocene glaciation in Prydz Bay, ODP Site 1166, Antarctica, Palaeogeogr., Palaeoclimatol., Palaeoecol. 198, 101111.

Tanahashi, M., T. Saki, N. Oikawa, S. Sato (1987), An interpretation of the multichannel seismic reflection profiles across the continental margin of the Dumond d'Urville Sea, off Wilkes Land, East Antarctica, in The Antarctic Continental Margin: Geology and Geophysics of Offshore Wilkes Land, edited by S. L. Eittreim, and M. A.Hampton, pp. 1-13, Circum-Pacific Council for Energy and Mineral Resources, Houston, Texas.

Tanahashi, M., S. L., Eittreim, and J. Wanneson, (1994), Seismic stratigraphic sequences of the Wilkes Land margin, Terra Antartica, 1, 2, 391-393. 